\title{
Nature and reactivity of silica available in rice husk and its ashes*
}

\author{
G RAMA RAO, A R K SASTRY and P K ROHATGI \\ Indian Institute of Chemical Technology, Hyderabad 500 007, India
}

\begin{abstract}
Scanning electron microscopy, reactivity and surface area measurements of rice husk and its ashes reveal the gradual formation of amorphous silica during ashing. The reactivity of the silica thus formed is found to be at its maximum for ashing temperatures between 400 and $600^{\circ} \mathrm{C}$ and hold-time from 6 to $12 \mathrm{~h}$. The reactivity of the ash is found to decrease with increasing temperature $\left(\geqslant 600^{\circ} \mathrm{C}\right)$ and hold-time.
\end{abstract}

Keywords. Rice husk; rice husk ash; lime reactivity.

\section{Introduction}

Rice husk ash contains mostly silica (90-95\%) besides minor amounts of calcium, magnesium, potassium, sodium, phosphorus and sulphur along with trace amounts of aluminium, manganese and iron which vary according to the soil and manures used, as shown in table 1. Compared to the conventional sources of silica, rice husk ash as a ceramic raw material possesses advantages like fine particle size and higher reactivity due to its amorphous nature. Though heap burnt ash (Misra and Borthakur 1985) and ash made by controlled burning (Chakrabarti et al 1985) are used equally well in making the high alite cements and forsterite ceramics for high frequency insulation, respectively, the reactivity of the ash varies with the ashing conditions and pre-ashing treatment of the hulls (Borthakur et al 1980).

The present study which describes the gradual changes in rice husk during ashing is undertaken to find out: (i) whether rice husk ashes from different places are the same and (ii) how the reactivity of the ash changes with ashing conditions.

\section{Experimental}

\subsection{Sample procurement and preparation}

Rice hulls and its heap burnt ash (pink coloured) were procured from the mill site at Balaramapuram near Trivandrum and husk only from the mill site at Amberpet in Hyderabad. Rice hulls were thoroughly washed to remove the dust accumulated at the mill site and dried at $40-45^{\circ} \mathrm{C}$ for seven days. Rice husk ash was made by using a box furnace or crucible furnace. The furnace temperature was raised in intervals of $100^{\circ} \mathrm{C}$. The port-hole of the furnace was kept open (in the case of the crucible furnace, the top cover was removed) for the emanating gases to escape. When no more gas or smoke evolved from the sample, the temperature of the furnace was further raised by another $100^{\circ} \mathrm{C}$. When the desired temperature was reached, the port-hole was closed (the top cover replaced in the case of the crucible furnace) and the sample was ashed for the required time.

*IICT Communication No. 2375 
Table 1. Analysis of rice husk ash.

\begin{tabular}{lcccc}
\hline & \multicolumn{4}{c}{ Weight \% of ash from } \\
\cline { 2 - 5 } Component & USA & Jorhat, Indiat & Trivandrum & Hyderabar \\
\hline $\mathrm{Si}$ as $\mathrm{SiO}_{2}$ & 94.50 & 94.5 & 91.4 & 89.4 \\
$\mathrm{Ca}$ as $\mathrm{CaO}$ & 0.25 & 0.48 & 0.17 & 2.55 \\
$\mathrm{Mg}$ as $\mathrm{MgO}$ & 0.23 & 0.23 & 1.30 & 1.30 \\
$\mathrm{Al}$ & Trace & 0.21 & 1.57 & 3.81 \\
$\mathrm{Fe}$ & Trace & 0.54 & 0.62 & 1.95 \\
$\mathrm{Mn}$ & Trace & 1.09 & 0.11 & 0.03 \\
$\mathrm{~K}$ as $\mathrm{K}_{2} \mathrm{O}$ & 1.1 & Trace & \multicolumn{2}{c}{ Not examined } \\
$\mathrm{Na}$ as $\mathrm{Na}_{2} \mathrm{O}$ & 0.78 & Trace & \multicolumn{2}{c}{ Not examined } \\
$\mathrm{P}$ as $\mathrm{P}_{2} \mathrm{O}_{5}$ & 0.53 & Trace & \multicolumn{2}{c}{ Not examined } \\
$\mathrm{S}$ as $\mathrm{SO}_{4}$ & 1.13 & Trace & \multicolumn{2}{c}{ Not examined } \\
\hline
\end{tabular}

*Hough and Barr (1956); †Borthakur et al (1980).

\subsection{Characterization and physical studies}

Electron microscopic studies of the hulls and the ashes were carried out using a JEOL scanning electron microscope. The X-ray powder patterns of the various ashes and ground husk were recorded using a Philips X-ray diffractometer. Surface area measurements were made employing the standard BET method.

Lime reactivity of the various ashes was determined by suspending a small quantity $(\sim 0.3 \mathrm{~g})$ of the ash in $50 \mathrm{ml}$ of saturated lime solution at room temperature and determining the drop in concentration of lime after $18 \mathrm{~h}$.

Alkali treatment of the husk was done by placing $75 \mathrm{~g}$ of husk in $500 \mathrm{ml}$ of $1 \mathrm{~N}$ sodium hydroxide solution for two weeks with stirring of the mixture, thrice a day. The husk was then washed free of alkali and dried at $40-45^{\circ} \mathrm{C}$ for seven days.

\section{Results and discussion}

\subsection{Microscopic examination of rice husk and its ash}

Scanning electron microscope (SEM) studies of rice husk and its ash are undertaken to get an understanding of the presence and distribution of silica present in the rice hulls. Micrographs of rice hull given in figure 1 show that the external appearance of the hull is very similar to corn on the cob. The needle-like structures that are on the hull at periodic intervals are probably the protective system against pests. Protuberances seen in the magnified picture form the exit points for the gases emanating when the hulls are ashed. The small grains that are spread over the epidermis are not artifacts but are evidently confined to it (Sharma et al 1984). Figure 2 shows the pictures of ash made at $300^{\circ} \mathrm{C}$ for $3 \mathrm{~h}$ and $6 \mathrm{~h}$. In these pictures we see the swelling and bursting of tips respectively, which indicates that the gaseous products formed due to ashing temperatures and time periods find their way out through the weakest spots of the structure.

The picture of rice husk ash made at $400^{\circ} \mathrm{C}$ for $1 \mathrm{~h}$, shown in figure 3 , indicates that the skin-like cellulosic material covering the internal skeletal structure starts 

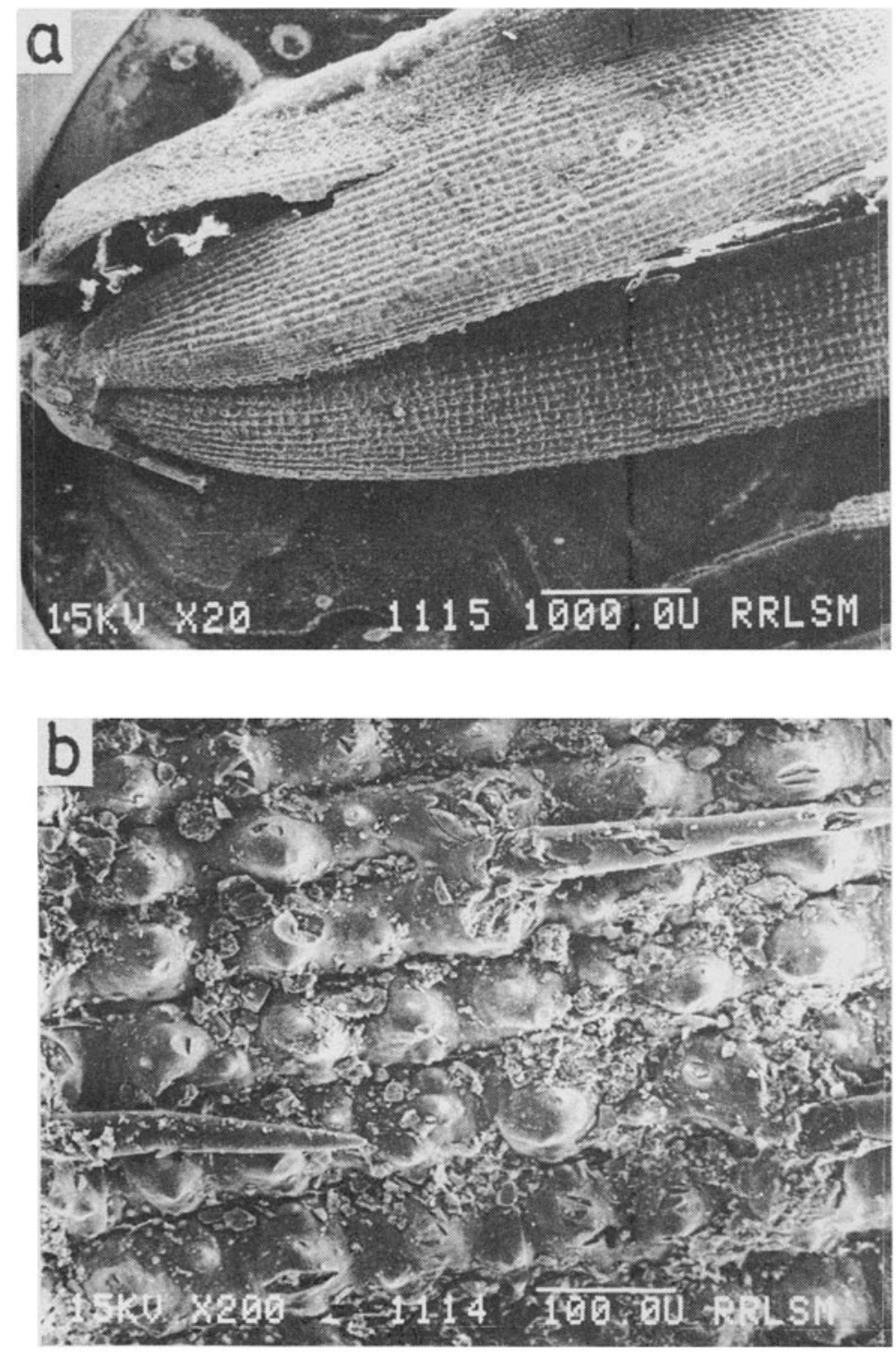

Figure 1. Scanning electron micrographs of rice husk (a) $20 \times$ and (b) $200 \times$.

burning off at this temperature. This process must be continuing with increase in temperature and time of ashing. Auger electron spectra studies (Sharma et al 1984) of the inner epidermis of the hull shows an Si peak only after sputtering with a $2 \mathrm{KV}$ argon ion beam for $1 \mathrm{~h}$. Moreover the shape of the $\mathrm{Si}_{\mathrm{LMM}}$ spectrum from this layer differs considerably from the published $\mathrm{Si}_{L M M}$ spectrum for $\mathrm{Si}$ in elemental silicon or $\mathrm{SiO}_{2}$. Hence it may be concluded that silica in rice husk does not exist as such but is formed on ashing from the skeletal structure seen in figure 3. Specimen preparation efforts for samples made at higher temperatures and times proved to be futile. 

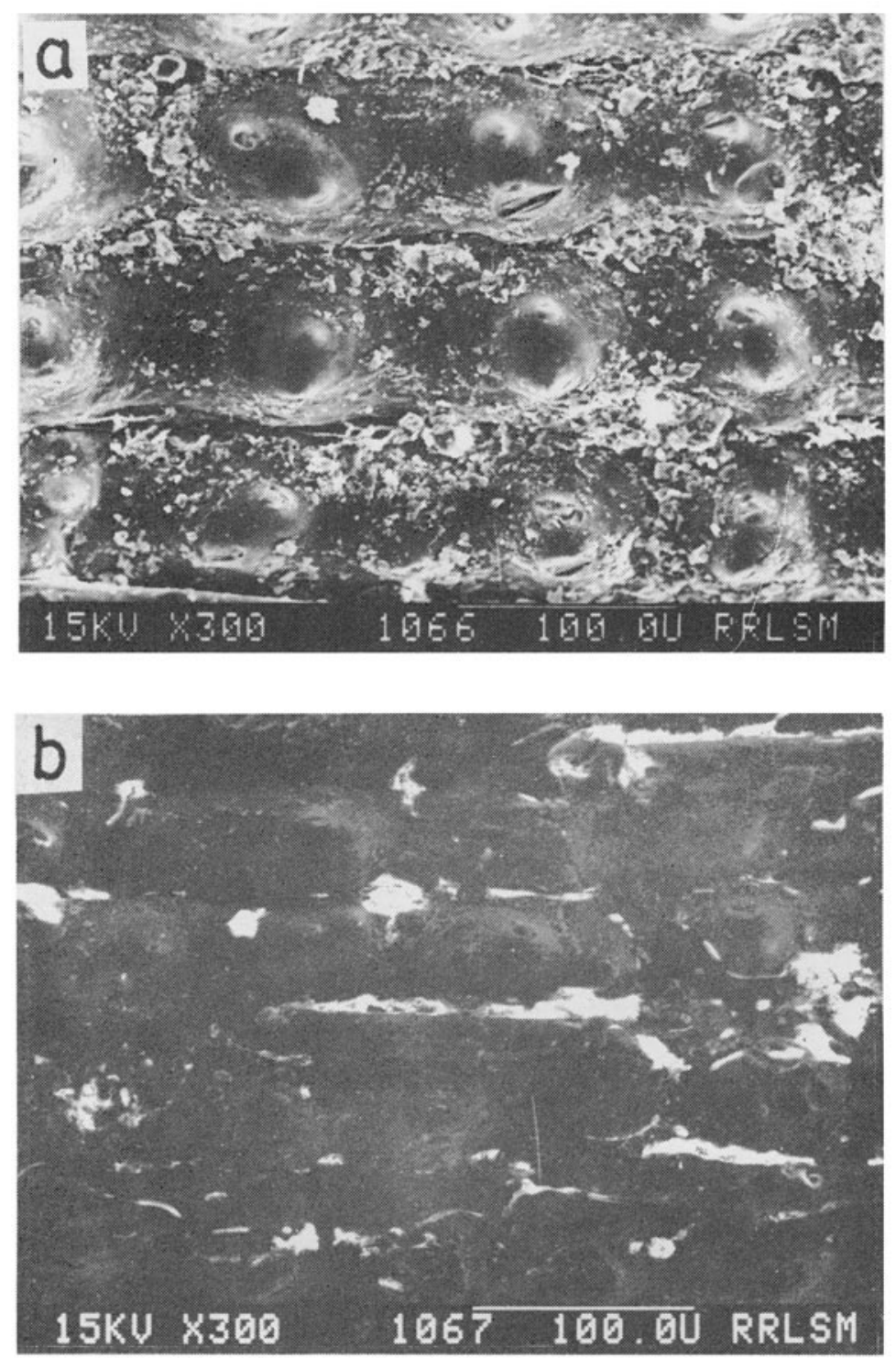

Figure 2. Scanning electron micrographs of rice husk ash made at (a) $300^{\circ} \mathrm{C}-3 \mathrm{~h}$ and (b) $300^{\circ} \mathrm{C}-6 \mathrm{~h}$.

The picture of ash made at $950^{\circ} \mathrm{C}-6 \mathrm{~h}$, the highest temperature and the associated maximum time of this study are shown in figure 4. From the ease with which this ash sample could be handled, like husk itself, as compared to the fragility of the samples made at temperatures from $500-850^{\circ} \mathrm{C}$, one can conclude that some sintering of the silica formed takes place, similar to loose stack sintering, during higher temperatures of ashing. Figure 4 shows that during ashing, the skin-like cellulose cover burns off and the main contribution to the silica content in the ash comes from the structure underneath it. 


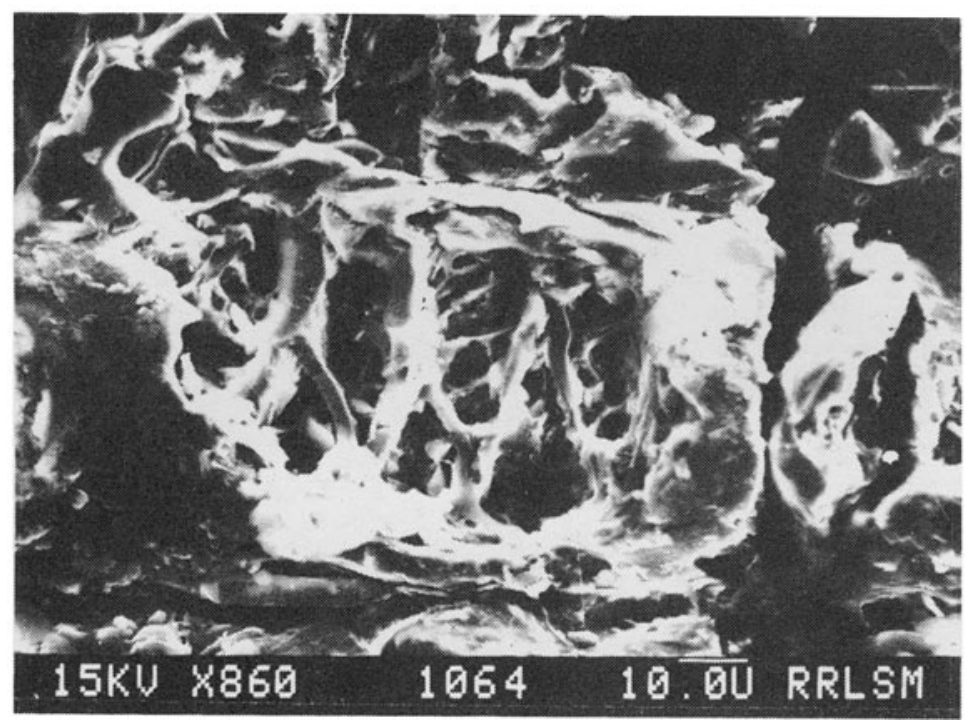

Figure 3. Scanning electron micrograph of rice husk ash made at $400^{\circ} \mathrm{C}-1 \mathrm{~h}$.

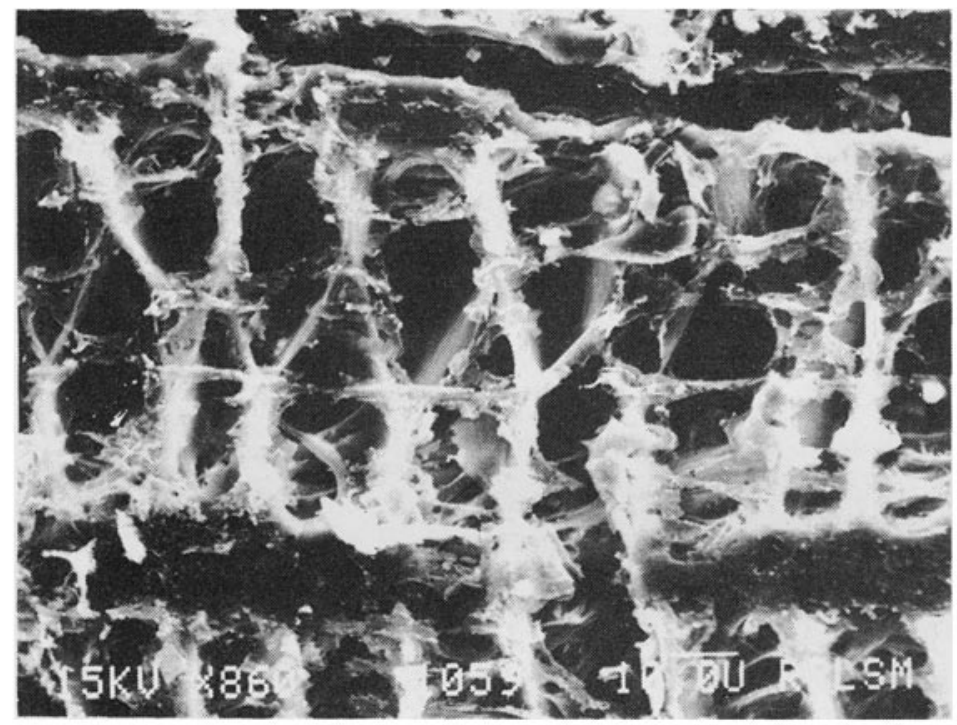

Figure 4. Scanning electron micrograph of rice husk ash made at $950^{\circ} \mathrm{C}-6 \mathrm{~h}$.

Sodium hydroxide-treated rice husk shown in figure 5 indicates that the alkali partially damaged the skin and made punctures on the surface at the weak spots (see figure 2). Higher magnification viewing in the holes made by the alkali did not reveal the skeletal structure as seen in figures 3 and 4 , indicating that the alkali has digested the silica-yielding structure underneath the cellulosic material. Ash yield obtained from the alkali-treated husk at $950^{\circ} \mathrm{C}-6 \mathrm{~h}$ is only 3.7 weight $\%$ compared to 


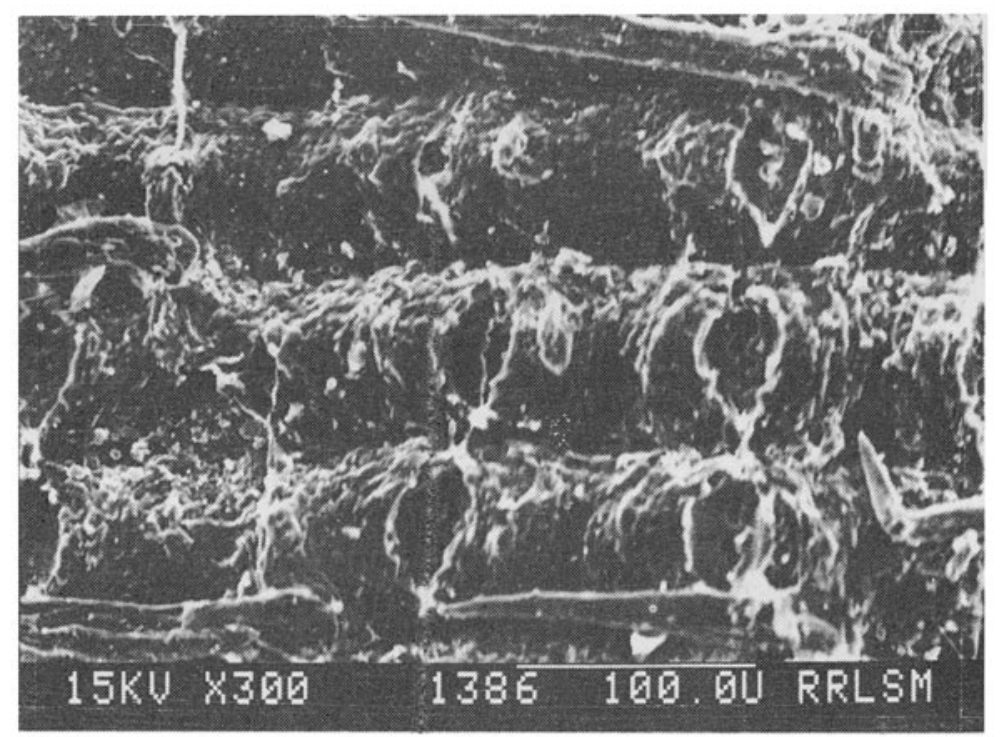

Figure 5. Scanning electron micrograph of $\mathrm{NaOH}$-ireated rice husk.

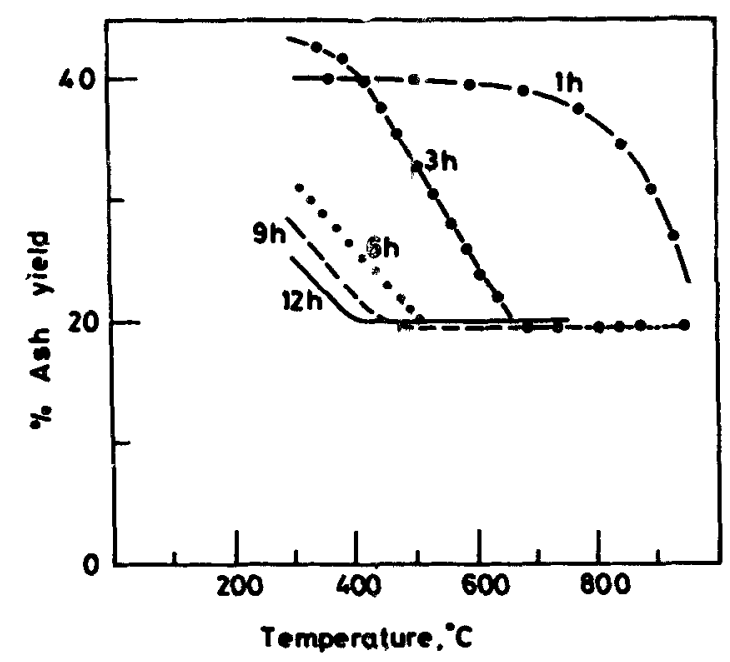

Figure 6. Weight $\%$ of ash yield as a function of ashing temperature for various holdtimes.

the $20 \%$ yield in the case of untreated husk, which indicates that the bulk of the silica in the hull is contained in between the inner and outer epidermis.

\subsection{Ash yield}

The ash-yields (weight \%) of rice husk made at various temperatures for different hold-times as shown in figure 6 indicate that the ultimate carbon-free ash yield is 
around $20 \%$, though the ash-yield for husk from different places may vary (ash yield from husk at Hyderabad is $\sim 24 \%$ ). It is also seen that with increase in holdtime, the temperature beyond which the ash yield is constant, decreases. In other words, one can completely burn the carbon content of the husk by choosing either higher temperatures and shorter hold times or vice versa (see table 2). In the case of $1 \mathrm{~h}$ hold-times, the ash yield very marginally decreases from 300 to $750^{\circ} \mathrm{C}$, showing a steep decrease only after $750^{\circ} \mathrm{C}$. This could be due to the slow burning nature of the tar, which is formed during the ashing of the husk, not getting oxidized until a sufficiently high temperature of about $750^{\circ} \mathrm{C}$ is reached.

\subsection{Reactivity of the ash}

Although one can obtain carbon-free ash by suitably choosing the temperature and hold-time, the reactivity of the silica formed during ashing can vary due to sintering effects or phase transitions, if any, or compound formation effects of the minor ingredients such as $\mathrm{Al}, \mathrm{Ca}, \mathrm{Mg}$, etc. Also it naturally follows that the reactivity of the carbon-containing black ash will be less than the white ash, which is carbon free. To examine this aspect, the lime reactivities of the different ashes made are estimated and are shown in figure 7 . It is seen that the \% lime reactivity of silica in the ash increases with increase in hold-time and attains a plateau-like value for temperatures of ashing up to $500^{\circ} \mathrm{C}$, showing the ineffectiveness of hold-time beyond a certain limit. In contrast to this behaviour, the \% lime reactive silica in the ashes made at $600^{\circ} \mathrm{C}$ and above attains a maximum with increasing hold-time and decreases thereafter. The maximum shifts to lower hold-times with increase in ashing temperature and finally, we see only the second half of the curve in the case of ash made at $950^{\circ} \mathrm{C}$. This may be happening due to one or more reasons mentioned earlier. To examine this; the following procedure is adopted.

(a) Rice husk ash samples made at $950^{\circ} \mathrm{C}-3 \mathrm{~h}, 950^{\circ} \mathrm{C}-6 \mathrm{~h}, 850^{\circ} \mathrm{C}-9 \mathrm{~h}$ and $750^{\circ} \mathrm{C}-$ $12 \mathrm{~h}$ were thoroughly ground to fine powder $(200 \mu)$, the lime reactivity measured and compared with that of the original samples. It is found that no regular pattern

Table 2. Colour of the ashes made at different temperatures for various hold-times.

\begin{tabular}{|c|c|c|c|c|c|c|c|c|}
\hline \multirow{2}{*}{$\begin{array}{l}\text { Hold-time } \\
\text { (h) }\end{array}$} & \multicolumn{8}{|c|}{ Temperature of ashing $\left({ }^{\circ} \mathrm{C}\right)$} \\
\hline & 300 & 400 & 500 & 600 & 650 & 750 & 850 & 950 \\
\hline 1 & Black & Black & Black & Black & Black & Black & Black & $\begin{array}{l}\text { Black \& } \\
\text { yellow }\end{array}$ \\
\hline 3 & $\begin{array}{l}\text { Black \& } \\
\text { white }\end{array}$ & $\begin{array}{l}\text { Black \& } \\
\text { white }\end{array}$ & $\begin{array}{l}\text { Black \& } \\
\text { yellow }\end{array}$ & $\begin{array}{l}\text { Black \& } \\
\text { yellow }\end{array}$ & $\begin{array}{l}\text { Black \& } \\
\text { yellow }\end{array}$ & $\begin{array}{l}\text { Black \& } \\
\text { yellow }\end{array}$ & $\begin{array}{l}\text { Black \& } \\
\text { yellow }\end{array}$ & $\begin{array}{l}\text { Dirty } \\
\text { yellow }\end{array}$ \\
\hline 6 & $\begin{array}{l}\text { Black \& } \\
\text { white }\end{array}$ & $\begin{array}{l}\text { Black \& } \\
\text { white }\end{array}$ & $\begin{array}{l}\text { Black \& } \\
\text { yellow }\end{array}$ & $\begin{array}{l}\text { Yellow \& } \\
\text { black }\end{array}$ & $\begin{array}{l}\text { Yellow \& } \\
\text { black }\end{array}$ & $\begin{array}{l}\text { Yellow } \\
\text { (cream) }\end{array}$ & Pink & $\begin{array}{l}\text { Dirty } \\
\text { pink }\end{array}$ \\
\hline 9 & $\begin{array}{l}\text { Black \& } \\
\text { white }\end{array}$ & $\begin{array}{l}\text { Black \& } \\
\text { white }\end{array}$ & $\begin{array}{l}\text { Dirty } \\
\text { whitish } \\
\text { yellow }\end{array}$ & Yellow & Yellow & $\begin{array}{l}\text { Yellow } \\
\text { (cream) }\end{array}$ & Pink & 一 \\
\hline 12 & $\begin{array}{l}\text { Black \& } \\
\text { white }\end{array}$ & $\begin{array}{l}\text { Black \& } \\
\text { white }\end{array}$ & $\begin{array}{l}\text { Dirty } \\
\text { yellow }\end{array}$ & Yellow & $\begin{array}{l}\text { Yellowish } \\
\text { pink }\end{array}$ & Pink & 一 & - \\
\hline
\end{tabular}




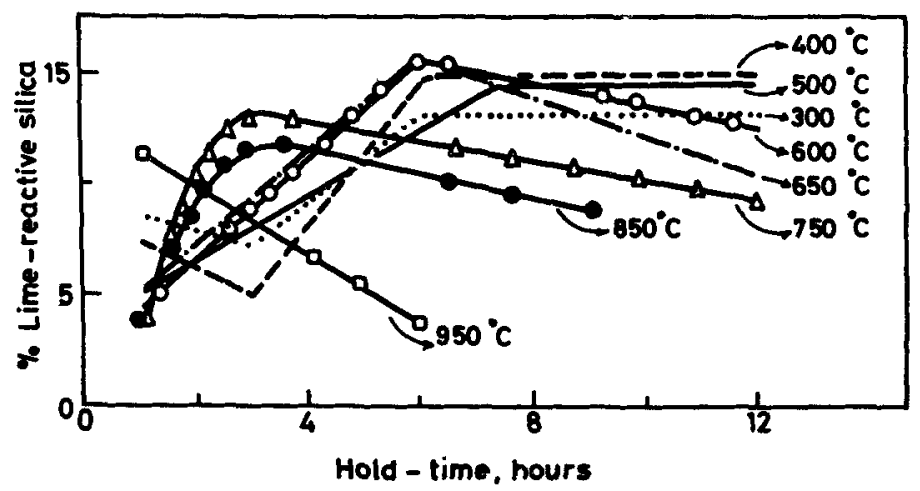

Figure 7. $(\%)$ Lime reactive silica in rice husk ashes as a function of hold-time, made at temperatures from 300 to $950^{\circ} \mathrm{C}$.

of increase in lime reactivity of the samples is seen except for fluctuations, though the particle size of the ashes had been reduced by about 3 to 4 times. This observation conclusively proves that sintering effects are not the cause for decrease in reactivity.

(b) Examination of the powder diffraction patterns of all the $6 \mathrm{~h}$ hold-time samples made at various temperatures (up to $950^{\circ} \mathrm{C}$ ) shows no other crystalline modification of silica except $\alpha$-quartz, which is seen in the ground rice husk pattern as well. In fact, the amorphous silica peak seen as a broad peak at $2 \theta=15-28^{\circ}(\mathrm{Cu}-\mathrm{K} \alpha)$ and centred around $2 \theta=21.85^{\circ}$ shows a small increase in intensity whereas the $\alpha$-quartz peak shows a decrease in intensity for samples made from 600 to $950^{\circ} \mathrm{C}$. As the lime reactivity of silica in principle should be more sensitive to the changes in the amorphous silica content rather than the changes in crystalline modifications like $\alpha$ quartz, this evidence obviously rules out the possibility of phase transitions causing the decrease in lime reactivity.

(c) Visual examination of the ash samples shows that as the temperature of ashing and hold-time are increased, the ashes undergo a change in colour progressively (see table 2). Rice hulls which are yellowish brown in colour at room temperature, go through the following sequence of colour on ashing, either with increase in temperature of ashing or hold-time:

$$
\begin{aligned}
& \text { Black } \rightarrow \text { White } \rightarrow \text { Yellow } \rightarrow \text { Pink } \rightarrow \text { Dirty pink } \\
& \begin{array}{llllll}
1 & 2 & 3 & 4 & 5
\end{array}
\end{aligned}
$$

(It may be noted that the ash obtained from rice husk at Hyderabad did not give this pink colour, but rather stopped with the white). The colour of the ashes immediately below or to the right of the solid line in table 2 indicates that these samples have already crossed the second stage in the above colour sequence. The second stage of colour is seen only in low temperature samples. But at higher temperatures of ashing, the colour changes of the above sequence take place in quick succession indicating the occurrence of chemical effects. In order to establish this conclusion experimentally, we have measured the lime reactivity of heapburnt ash (pink-coloured) and pure white heap burnt ash prepared using $50 \%$ hydrochloric acid as leachant. The lime reactivity had increased by nearly $35 \%$ in 
the white ash made by leaching, compared to that of heap burnt ash. The chemical analysis of the white ash made by leaching treatment is as follows: $\mathrm{Si}$ as $\mathrm{SiO}_{2}-$ 98.7\%; $\mathrm{Al}-0.7 \% ; \mathrm{Fe}-0.09 \% ; \mathrm{Mn}$-trace and $\mathrm{Mg}$ and $\mathrm{Ca}-$ not detectable. This data in comparison to that given in table 1 clearly indicates that the minor constituents in husk act as inhibitors of lime reactivity of silica when ashed at higher temperatures. (On the other hand, the presence of minor ingredients in the rice husk ash is found to be advantageous to whisker growth in the case of SiC whiskers made from rice hulls, Nutt 1988). As the \% lime reactivity shows a saturation for samples made at or below $500^{\circ} \mathrm{C}$ and a maximum with a decrease thereafter for samples made at or above $600^{\circ} \mathrm{C}$ (figure 7), it is evident that the above envisaged chemical effect is occurring between 500 and $600^{\circ} \mathrm{C}$. It is also inferred that for temperatures of ashing at $600^{\circ} \mathrm{C}$ and above, there is a threshold of hold-time, below which the \% lime reactivity of silica formed increases and beyond which it decreases. The rate of increase and decrease of $\%$ lime reactivity varies with the ashing temperature, becoming steeper at higher temperatures.

Figure 8 shows the \% lime reactivity of the samples made for different hold-times as a function of the temperature of preparation. It is seen that except for $1 \mathrm{~h}$ holdtime samples, lime-reactivity shows a peak for every hold-time and the temperature at which the peak occurs progressively shifts to lower temperatures with increasing hold-time. The plot for $1 \mathrm{~h}$ hold-time in figure 8 looks a bit odd compared to the rest of the curves, though it will not be on closer examination. If we compare the $1 \mathrm{~h}$ hold-time curves from figures 6 and 8, the validity of the above statement can be very easily understood. Because of the slow oxidative nature of the carbonized hulls in the static air atmosphere of the furnace, increase of temperature from 300 to $750^{\circ} \mathrm{C}$ for $1 \mathrm{~h}$ hold-time does not cause much significant change in the $\%$ ash yield. Only beyond $750^{\circ} \mathrm{C}$, the $\%$ ash yield decreases, indicating that the carbon content of the ash is decreasing. This is exactly the temperature at which $\%$ lime reactivity for the $1 \mathrm{~h}$ sample (figure 8 ) begins to increase, which obviously means that more reactive silica is forming as the ash continues to oxidise its carbon content.

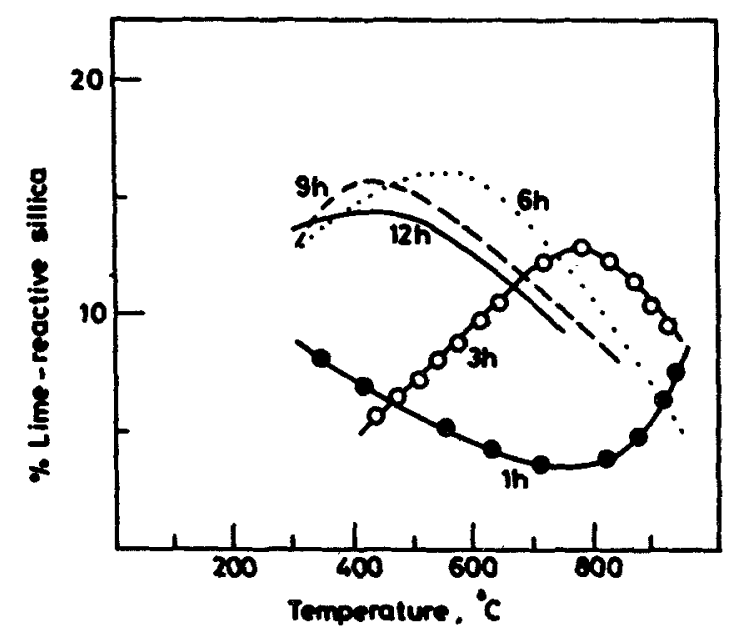

Figure 8. (\%) Lime reactive silica in ash samples made for different hold times, as a function of ashing temperature. 
The logical question that arises at this stage is why the \% lime reactivity curve for $1 \mathrm{~h}$ hold-time in figure 8 shows a decrease from 300 to $750^{\circ} \mathrm{C}$ instead of a marginal increase. The only explanation that can be offered at this juncture is that, while the $\%$ ash yield marginally decreases from 300 to $750^{\circ} \mathrm{C}$ not much of fresh silica that can react with lime is being formed. On the other hand, whatever silica that is formed initially must be becoming inactive due to the decrease in surface area as well as chemical effects.

\subsection{Surface area measurements}

Surface area measurements on samples made at $300-950^{\circ} \mathrm{C}$ for $6 \mathrm{~h}$ (figure 9) show that sintering effects become quite predominant for temperatures of ashing of $600^{\circ} \mathrm{C}$ and above, though sintering is not the exact cause for reduction in lime reactivity of the samples made at higher temperatures.

\section{Conclusions}

(i) Ashes of rice husk made at temperatures of $400^{\circ} \mathrm{C}$ and below contain unburnt cellulosic material.

(ii) Sintering effects start showing up for ashes made at $600^{\circ} \mathrm{C}$ and above and the surface area of the silica formed gets drastically reduced with increasing sintering temperature.

(iii) Reactivity of the silica in the ash decreases due to chemical effects for temperatures of ashing like $600^{\circ} \mathrm{C}$ and above, becoming more and more predominant with increasing temperatures of ashing.

(iv) Only ashes made at $400^{\circ} \mathrm{C}$ for 6 to $12 \mathrm{~h}$ and at $500^{\circ} \mathrm{C}$ for 8 to $12 \mathrm{~h}$ have maximum reactivities and margins of hold-time, whereas samples made at temperatures of $600^{\circ} \mathrm{C}$ and above have their reactivities going through maximum values and deteriorating thereafter, making the hold-time critical for maximum reactivity.

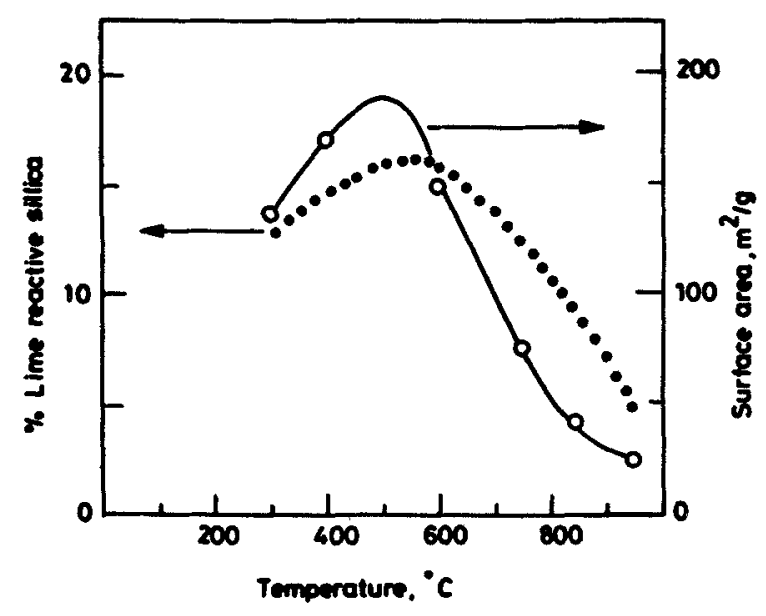

Figure 9. Surface areas of ash samples made at different temperatures for a hold-time of $6 \mathrm{~h}$. 


\section{Acknowledgements}

The authors' thanks are due to Dr A V Rama Rao for his encouragement. They also gratefully acknowledge the Regional Research Laboratory (RRL), Trivandrum, for the facilities provided during a major portion of this work, Dr Joy of Travancore Titanium Products, Trivandrum, for X-ray facilities, Dr B Viswanathan of the Indian Institute of Technology, Madras, for surface area measurements and the assistance of $\mathrm{Mr}$ P Jayachandran of RRL, Trivandrum.

\section{References}

Borthakur P C, Saikia P C and Dutta S N 1980 Ind. Ceram. 2325

Chakrabarti M, Virkar A N and Maiti H S 1985 Trans. Indian Ceram. Soc. 441

Hough J H and Barr H T 1956 USDA Bull, 507

Misra K C and Borthakur P C 1985 Trans. Indian Ceram. Soc. 44101

Nutt S R 1988 J. Am. Ceram. Soc. 71149

Sharma N K, Williams W S and Zangvil A 1984 J. Am. Ceram. Soc. 67715 